\title{
COVID-19: Africa's Challenge and the Need for a Paradigm Shift on the Use of Ventilators
}

\author{
Jude-Kennedy C. Emejulu1,2*, Yewande Anne Motunrayo Emejulu ${ }^{2,3}$, Enoch Ogbonnaya Uche ${ }^{4,5}$ \\ ${ }^{1}$ Department of Surgery, Faculty of Medicine, College of Health Sciences, Nnamdi Azikiwe University, Awka, Nigeria \\ ${ }^{2}$ Nnamdi Azikiwe University Teaching Hospital, Nnewi, Nigeria \\ ${ }^{3}$ Department of Nursing Sciences, Faculty of Health Sciences and Technology, College of Health Sciences, Nnamdi Azikiwe \\ University, Awka, Nigeria \\ ${ }^{4}$ Department of Surgery, Faculty of Medical Sciences, College of Medicine, University of Nigeria Enugu Campus, Enugu, Nigeria \\ ${ }^{5}$ University of Nigeria Teaching Hospital, Ituku, Nigeria \\ Email: ^judekenny2003@yahoo.com, ^j.emejulu@unizik.edu.ng, emejuluw@gmail.com, kechyenny@yahoo.com, \\ enoch.uche@unn.edu.ng
}

How to cite this paper: Emejulu, J.-K.C., Emejulu, Y.A.M. and Uche, E.O. (2020) COVID-19: Africa's Challenge and the Need for a Paradigm Shift on the Use of Ventilators. International Journal of Clinical Medicine, 11, 420-430.

https://doi.org/10.4236/ijcm.2020.116035

Received: May 10, 2020

Accepted: June 14, 2020

Published: June 17, 2020

Copyright $\odot 2020$ by author(s) and Scientific Research Publishing Inc. This work is licensed under the Creative Commons Attribution International License (CC BY 4.0)

http://creativecommons.org/licenses/by/4.0/

\begin{abstract}
Background: The December 2019 Chinese epidemic of Corona Virus Disease [COVID-19], which erupted in Wuhan, South China, was declared a pandemic, by the World Health Organization [WHO], on $12^{\text {th }}$ January 2020. The worldwide spread from China was rapid, but Africa was the last port-of-call. Her first diagnosed case was two months after China's, on $14^{\text {th }}$ February, 2020 in Egypt. The morbidity and mortality rates have, however, remained lower in Africa than in the developed world, and analysts believe that it was more of a temporary respite, since Africa's poor health infrastructure will become her eventual albatross. Methodology: Data were collected on COVID-19 and records of the socio-economic capacity of Africa by accessing the relevant previous and current peer-reviewed publications from multiple search engines on internet. The data were, then, collated and comparatively analyzed. Results: The available data revealed that Africa had, mostly, the milder forms of COVID-19, and so, morbidity and mortality were low. Her shrinking elderly population and hot climate were believed to be contributory, but lately, as the pandemic spread, the role of these factors was not exactly predictive. Being low on healthcare infrastructure, Africa could tenaciously leverage on the supportive and preventive measures prescribed by WHO, while the world awaited a vaccine. The role of ventilators in the care of critically ill patients, also, came under scrutiny as some workers were questioning the underlying pathology, and advocating a paradigm shift from high-tech positive end expiratory pressure ventilation to plasmapheresis and packed cell transfusion. Conclusion: Africa faces a huge challenge with COVID-19, but the predicted heavy mortalities may be reduced by some local confounding factors, control
\end{abstract}


of spread and re-focusing of critical care away from the expensive and unavailable ventilators.

\section{Keywords}

Blood Failure, China, Confirmed Cases, Cytokine Storm, Deaths, Egypt, Interleukin-6 as Biomarker, Packed Cell Transfusion, Respiratory Failure, Plasmapheresis, SARS-CoV-2, USA

\section{Introduction and Overview of COVID-19}

\section{Background}

The 2019 Chinese epidemic of Corona Virus Disease [COVID-19], which erupted in a local Seafood Market in Wuhan, South China, at the end of 2019, was declared a pandemic by the World Health Organization [WHO], on $12^{\text {th }}$ January 2020 [1] [2] [3]. The causative organism was identified and code-named SARS-CoV-2, by WHO [4].

Spread

The spread from China was rapid, all around the world, but Africa was the last port-of-call, recording her first confirmed case in Egypt on $14^{\text {th }}$ February, followed by Nigeria $25^{\text {th }}$ February, Morocco $3^{\text {rd }}$ March and South Africa $5^{\text {th }}$ March, 2020 .

Tissue Concentration of the Virus

When the virus gains entry into the human body, it concentrates mostly in the respiratory system, and saliva. On account of this, any of four secretions are useful in screening for SARS-CoV-2: sputum, throat swab, respiratory tract secretions and saliva [5]. The focus of the treatment of COVID-19 is, logically, on the respiratory tract, where it concentrates.

\section{Interleukin-6 as a Biomarker for Poor Prognosis}

In critically ill patients, the inflammatory cytokine, interleukin-6 [Il-6], levels increase significantly, to almost 10 times the normal levels. This high rise is correlated to the detection of RNAaemia. Remarkably, also, all cases of death exhibited high levels of Il-6, suggesting that it as an important biomarker for poor prognosis [6].

Classification

There are two classes of COVID-19, based on the effects on the respiratory system, where it predominantly manifests. These are: Asymptomatic and Symptomatic, both of which are contagious and can transmit the disease. The symptomatic COVID-19 is sub-classified into: 1) Mild 2) Moderate 3) Severe 4) Critical; based on the intensity of hypoxaemia and progression to multiple organ dysfunction syndrome [MODS].

\section{Post-mortem Findings}

Sharif Sultan, recently, reported that, based on the observations from postmortem studies done on deceased COVID-19 patients, there was a consistent 
finding of pulmonary thrombosis, which was not typical of Acute Respiratory Distress Syndrome [ARDS]. Also, that the hypoxaemia found in the patients did not respond to PEEP ventilation, but to high oxygen flow [7]. And so, he advised that patients be started early on maximum oxygen flow, until ventilation becomes inevitable.

\section{Molecular Findings, Cytokine Storm and Failure of Haemoglobin}

The viral structural protein, was discovered to stick to haeme, displacing oxygen releasing iron-free ion, and leading to toxicity at the pulmonary bed with inflammation of alveolar macrophages. The virus attacks the beta chain of haemoglobin, dissociates haeme and removes the iron converting it to porphyrin, and leading to "failure of blood" to carry oxygen. The underlying pathology, therefore, is not "failure of respiration".

The oxidative iron released from the haemolysed blood cells damages the lungs, leading to an abnormal rise in levels of Il-6 which becomes the hallmark and driving force of the associated Cytokine Storm, that leads to MODS [7]. The final common pathway, therefore, is the metabolic hypoxia from blood organ failure.

The physiological implication of this is that an invasive ventilation will not be of the best benefit, rather, frequent plasmapheresis and transfusions, to replace the compromised haemoglobin and boost the oxygen-carrying capacity, will be more beneficial in ameliorating the Cytokine Storm [7].

This study evaluates the current status of COVID-19 around the world and the challenges facing the resource-poor African nations. It, then, suggests a paradigm shift from mandatory mechanical ventilation to mandatory plasmapheresis and packed cell transfusion in the management of COVID-19.

Data were collected on the available body of knowledge on COVID-19 and socio-economic capacity of African countries, from multiple search engines on internet. The results collected from all the sources were collated and presented in prose, tables and a graph and analyzed.

\section{Methodology}

Data were collected on COVID-19 and records of the socio-economic capacity of African countries by accessing the relevant previous and current peer-reviewed publications from multiple search engines on internet. The data were, then, collated and comparatively analyzed.

\section{Results}

\section{Statistics on SARS-CoV-2 Infection around the World}

Within the first 4 months of the pandemic, [ $30^{\text {th }}$ April, 2020], some 160 [of 212] countries around the world had been infected, with a total of 3,304,309 cases confirmed COVID-19 positive. Out of those, 1,980,404 were mild [97\%] and 50,950 [3\%] severe/critical infections. There were 233,839 deaths, and 1,039,104 recoveries [8] [9] [10]. China, the source of the coronavirus, had 82,874 confirmed cases, 4633 deaths and 77,642 recoveries [11]. And, there were the 300 
million non-infected pupils worldwide, who were taken off schools and asked to stay at home, until the pandemic came under control.

The USA topped the world list with 1,095,019 confirmed cases, 1,039,136 recoveries and 63,856 deaths; followed by Spain with 239,639 cases, 137,984 recoveries and 24,543 deaths; Italy 205,463 cases, 75,945 recoveries and 27,967 deaths; UK 171,253 cases and 26,771 deaths; France 167,178 cases, 49,476 recoveries, 24,376 deaths; and Germany 163,009 cases, 123,500 recoveries and 6623 deaths [12]. As the UK and French figures rose rapidly, the German figures rose less rapidly, just as her comparative death rates, as well. Surprisingly, China, with the largest population in the world [1.4 billion], came a distant $11^{\text {th }}$, and did not even make the Top-10; see Table 1.

\section{Impact on Africa}

In Africa, by the end of April, 52 out of her 54 countries were already infected, with 39,713 confirmed cases, 13,070 recoveries, and 1,638 deaths. Out of these, South Africa was the worst hit with 5647 confirmed cases, followed by Egypt with 5537 cases and Morocco 4423 cases.

But, Algeria with 4006 cases, 1779 recoveries and 450 deaths, had the worst outcome amongst the African nations. Ghana was $5^{\text {th }}$ with 2074, cases; Nigeria was $6^{\text {th }}$ with 1932 cases, and Cameroon $7^{\text {th }}$ with 1832 cases; see Table 2 [13].

Table 1. World's top 10 countries with COVID-19 [16] [30 ${ }^{\text {th }}$ April, 2020].

\begin{tabular}{lccc}
\hline \multicolumn{1}{c}{ Country } & Confirmed Cases & Recoveries & Deaths \\
\hline 1. USA & $1,095,023$ & 152,324 & 63,856 \\
2. Spain & 239,639 & 137,984 & 24,543 \\
3. Italy & 205,463 & 75,945 & 27,967 \\
4. United Kingdom & 171,253 & $\mathrm{~N} / \mathrm{A}$ & 26,771 \\
5. France & 167,178 & 49,476 & 24,376 \\
6. Germany & 163,009 & 123,500 & 6623 \\
7. Turkey & 120,204 & 48,886 & 3174 \\
8. Iran & 94,640 & 70,933 & 6028 \\
9. Russia & 106,498 & 11,619 & 1073 \\
10. Brazil & 87,187 & 35,935 & 6006 \\
11. China & 84,338 & 77,474 & 4642 \\
\hline
\end{tabular}

Table 2. Africa's top 10 countries with COVID-19 [8] [13] [17] [18] [19] [20] [30 $0^{\text {th }}$ April, 2020].

\begin{tabular}{lccc}
\hline \multicolumn{1}{c}{ Countries } & Confirmed Cases & Recoveries & Deaths \\
\hline 1. South Africa & 5647 & 2073 & 103 \\
2. Egypt & 5537 & 1381 & 392 \\
3. Morocco & 4423 & 984 & 170 \\
4. Algeria & 4006 & 1779 & 450 \\
5. Ghana & 2074 & 212 & 17 \\
6. Nigeria & 1932 & 319 & 58 \\
7. Cameroon & 1832 & 934 & 61 \\
8. Cote d'Ivoire & 1164 & 499 & 14 \\
9. Guinea & 1495 & 329 & 7 \\
10. Djibouti & 1089 & 846 & 2 \\
\hline
\end{tabular}


The Nigerian Centre for Disease Control [NCDC] equally reported a total of 13,500 tests done by this time, and a plan to increase testing capacity to 3500 tests daily; while South Africa led Africa with 60,000 tests already done, and an existing capacity for 10,000 tests, daily [14] [15].

\section{Discussion}

Africa appeared lucky with her much lower incidence and mortality rates than the rest of the world; and the worst hit African country was South Africa with 5647 cases, though Algeria had the highest mortality rate, followed by Egypt; see Table 2.

\section{The Infamous "Bleak Situation" in Our Continent}

Being that massive resources are required for the diagnosis and treatment of patients, protection of the care givers and community, as well as research, with a hope to developing a cure, or, vaccine, Africa's capacity to cope with this pandemic appears to be, unarguably, sub-optimal. Observers believed that the African situation was like a ticking time-bomb, and that, it was just a matter of time before the pandemic will overrun the continent. A few disagree on account of some observed factors.

Immunity by Default?

At the outbreak of the pandemic, there appeared to be in Africa:

1) a lytic hot climate, adverse to the survival of SARS-CoV-2, which showed a predilection to the cold regions;

2) a viral strain, Type B mostly, which was less toxigenic;

3) the factor of low population of elderly persons, due to her lower life expectancy, from poverty and disease.

Perhaps, these 3 variables explained the lower morbidity and mortality rates in Africa; but, may well be confounding factors, only.

Capacity for the Care of the Severely Ill Cases in Africa

In Africa [population 1.2 billion], the total number of COVID-19 cases was 39,713 confirmed cases, which was $3.63 \%$ the figure for USA [population 331 million] [20] [21] [22]. Yet, it is noteworthy that in Africa, the volume and quality of essential expertise, equipment and infrastructure, for the intensive care of critically ill persons, are grossly inadequate.

Kenya, for example, had 200 intensive care [ICU] beds for her 50 million citizens, i.e. a ratio of one ICU bed to 250,000 citizens; whereas, the USA had 34 ICU Beds [could be up to 45] per 100,000 persons [23]. The ICU bed ratio of USA translated to 85 - 100 times disparity against Kenya.

\section{African Initiatives}

Learning from the experiences of their forebears in the COVID-19 pandemic in USA, Asia and Europe, many African states adopted some indigenous measures to contain COVID-19 [24]. Madagascar produced an organic drink from the antimalarial, artemisia, which was reported to reduce the mortality from COVID-19 [25]. Senegal, with UK government and Bill and Melinda Gates Foundation, adapted the screening kit originally used for Dengue Fever to a 
cheap \$1 COVID-19 quick diagnostic kit [26]. The Senegalese researchers, also, designed an affordable ventilator, costing $\$ 60$ each, as against $\$ 16,000$ for each imported unit in the country which had only 50 ventilators for her 16 million population [27].

\section{Abuja Declaration on Health Budgets of African Nations}

At the April 2001 Abuja Declaration, African Heads of Government under the auspices of the WHO, agreed to allot, at least, $15 \%$ of total annual budgets to health [28]. After the first decade following that Declaration, only one African country met that target, and 11 actually reduced their budgets. Nigeria's health budget range, very embarrassingly, averaged at $4 \%-6 \%$ since the Abuja Declaration [29].

\section{WHO Recommendations on Healthcare Personnel and Equipment}

The WHO recommends 1 doctor to 1000 persons; 1 nurse to 1 patient in ICU [1 nurse to 2 or 3 acutely ill but stable patients]; and 1 nurse to 500 persons; see Table 3 and Figure 1 [28] [29] [30]. Other WHO recommendations include: one ICU bed/10,000 persons, and a 50-bed hospital/100,000 persons. On none of these counts do the African countries meet the recommendations, whereas all the World Top-5 COVID-19 countries exceeded the WHO benchmarks.

Amongst the Top-5 African COVID-19 affected countries, only Algeria [1.8per-1000] met the WHO recommendation of 1 doctor per 1000 persons, whereas all the World's Top-5 affected countries had more than double the recommendation. This is a further illustration of the low manpower capacity of Africa in healthcare services.

Curiously, the world's Top- 5 had the highest infection and death rates globally, demonstrating the massive impact on their resources. It can best be imagined how the African countries could cope if the infection rates rise to those of the developed economies.

Table 3. Comparison of doctor-to-patient ratio [Physician Density per 1000 Persons] between Top-5 COVID-19 infected nations in the World and Top-5 of Africa [31] [32].

\begin{tabular}{lccc}
\hline \multicolumn{1}{c}{ Country } & Population [million] & Confirmed COVID-19 Cases & Doctor/1000 Pop \\
\hline & \multicolumn{3}{c}{ Africa's Top-5 } \\
1. South Africa & 60 & 5647 & $0.9[2017]$ \\
2. Egypt & 102 & 5537 & $0.814[2014]$ \\
3. Morocco & 40 & 4423 & $0.7[2017]$ \\
4. Algeria & 44 & 4006 & $1.8[2016]$ \\
5. Ghana & 31 & 2074 & $0.2[2017]$ \\
& & & \\
6. USA & 331 & $1,000,000$ & $2.6[2016]$ \\
7. Spain & 47 & 220,000 & $4.1[2016]$ \\
8. Italy & 60 & 199,000 & $4.021[2016]$ \\
9. Germany & 84 & 158,000 & $4.191[2015]$ \\
10. UK & 68 & 153,000 & $2.825[2017]$ \\
\hline
\end{tabular}




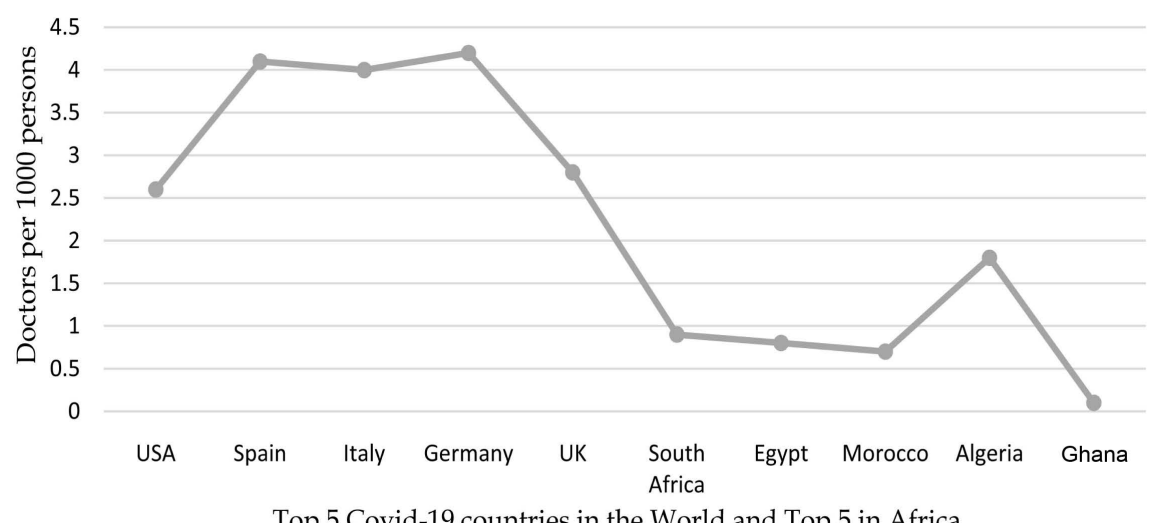

Figure 1. Graphic representation of doctors-per-1000-persons ratios in the World's top-5 and Africa's top-5 COVID-19 infected countries.

Evaluating the availability of ventilators, Nigeria had an estimated 370 units for 206 million citizens; an average of 1 to 560,000 persons, compared to USA with 150,000 ventilators for 331 million citizens, a ratio of 1 per 2200 persons [15] [33] [34] [35] [36] [37]. Meanwhile, with COVID-19, the ventilator is a major respiratory back up, in severe stages, against failing respiration and death [30] [35]. The disparity between Africa and the developed nations is very scandalous; see Table 4.

If the $\$ 16,000$ cost per unit, of an imported ventilator in Senegal, is used as benchmark, it becomes a herculean task for any of the African Top-10 affected countries, whose highest income per capita [Algeria $\$ 15,293$ ] is $25 \%$ of that of USA $[\$ 59,928]$, to procure enough ventilators to match the ratio of any of the World's Top-10 affected countries; see Table 5.

And so, what are the options available to Africa?

By April 2020, Senegalese researchers had begun the production of very cheap ventilators at $\$ 60$ per unit [cc: $\$ 16,000 /$ imported unit], and, if these can be mass-produced, Africa will improve on her current ventilator/100,000 persons ratios, to a good extent [27]. But those may be reserved for just the critical cases.

Sultan had in his report clearly enunciated the pathological basis for the respiratory difficulties and Il-6 Cytokine Storm in COVID-19, and gone ahead to proffer the solution of plasmapheresis and packed cell transfusion, with maximum oxygen flow, as more effective than PEEP ventilation [7].

At the average cost of $\$ 40$ per unit of blood and $\$ 400$ for 10units in the African countries, it appears that multiple transfusions will even be 400 times cheaper [ $\$ 400$ vs. $\$ 16,000]$ than the hardware of a mechanical ventilator. It, therefore, behooves the African nations to adopt the Sultan prescription along with existing management protocols which may be more cost-effective, pragmatic and efficient for them, even on an experimental basis, than investing their little income-per-capita on just a few ventilators at the critical stage of COVID-19. 
Table 4. Comparison of ventilator-to-persons ratio between African countries and USA [38] [39].

\begin{tabular}{lccc}
\hline \multicolumn{1}{c}{ Country } & $\begin{array}{c}\text { Population } \\
\text { [millions }\end{array}$ & $\begin{array}{c}\text { Total No. } \\
\text { of Ventilators }\end{array}$ & Ventilator Ratio/100,000 \\
\hline 1. Senegal & 16 & 200 & $1.25 / 100,000$ \\
2. Nigeria & 206 & 370 & $0.184 / 100,000$ \\
3. South Africa & 59 & 6000 & $10 / 100,000$ \\
4. Egypt & 102 & 6000 & $6 / 100,000$ \\
5. USA & 331 & 150,000 & $45 / 100,000$ \\
\hline
\end{tabular}

Table 5. Distribution of income per capita of the Top-10 COVID-19 affected countries in Africa and the world [40].

\begin{tabular}{lclc}
\hline \multicolumn{1}{c}{ Country } & Income Per Capita [\$] & \multicolumn{1}{c}{ Country } & Income Per Capita [\$] \\
\hline 1. South Africa & 13,526 & 1. USA & 59,928 \\
2. Egypt & 11,608 & 2. Spain & 39,037 \\
3. Morocco & 8225 & 3. Italy & 40,924 \\
4. Algeria & 15,293 & 4. United Kingdom & 44,920 \\
5. Cameroon & 3722 & 5. France & 44,033 \\
6. Ghana & 4502 & 6. Germany & 52,556 \\
7. Nigeria & 5887 & 7. Turkey & 28,002 \\
8. Cote d'Ivoire & 3945 & 8. Iran & 20,885 \\
9. Guinea & 2247 & 9. Russia & 25,763 \\
10. Djibouti & N/A & 10. Brazil & 15,553 \\
\hline
\end{tabular}

In the long term, nevertheless, the more impacting factors like poverty, malnutrition, corruption and endemic diseases, which pre-dated COVID-19, along with the poor healthcare infrastructure, have to be resolutely addressed by all African nations, as a priority.

\section{Conclusions}

With COVID-19, Africa is going to face harder times ahead, because of the protracted negligence of the health infrastructure of her countries over the decades; and so, despite the initial low morbidity and mortality rates, there is a possibility that these figures may rise astronomically.

Developing countries need to adopt home-grown indigenous hygienic and health promotional measures to successfully fight COVID-19.

If, however, the lockdown remains imperative, appropriate measures should be taken to avert both food and economic crises, by ensuring that food supply lines and essential businesses are sustained.

Africa should immediately explore the prospects of plasmapheresis and packed cell transfusion as a cheaper and more efficient treatment protocol for critically 
ill COVID-19 patients. The absolute dependence on mechanical ventilators, which are both expensive and in short supply, should be reserved for the critical cases.

\section{Disclosures}

I have nothing to disclose; I have no commitment whether financial, intellectual or philanthropic to any of the references or institutions or companies cited and I have no form of payment or gratification to any individual or group, whatsoever.

\section{Conflicts of Interest}

The authors declare no conflicts of interest regarding the publication of this paper.

\section{References}

[1] Pneumonia of Unknown Cause-China (2020) https://www.who.int/csr/don/05-january-2020-pneumonia-of-unkown-cause-china len/

[2] Li, Q., Guan, X., Wu, P., Wang, X., Zhou, L., Tong, Y., et al. (2020) Early Transmission Dynamics in Wuhan, China, of Novel Coronavirus-Infected Pneumonia. The New England Journal of Medicine, 382, 1199-1207. https://doi.org/10.1056/NEJMoa2001316

[3] CDC-OPHSS-CSELS-Division of Labour (2020) Outbreak of 2019 Novel Coronavirus (2019-nCoV) in Wuhan, China.

https://www.cdc.gov/csels/dls/locs/2020/outbreak-of-2019-novel-coronavirus-2019ncov-in-wuhan-china.html

[4] National Health Commission of People's Republic of China (2020) Prevention Guidelines of 2019 nCoV, 6 ED, Part I. http://en.nhc.gov.cn/2020-04/05/c_78815.htm

[5] Azzi, L., Carcano, G., Giafagna, F., Grossi, P., Gasperina, D.G., Genoni, A., et al. (2020) Saliva Is a Reliable Tool to Detect SARS-CoV-2. Journal of Infection, 9, 57. https://doi.org/10.1016/j.jinf.2020.04.005

[6] Chen, X.H., Zhao, B.H., Qu, Y.M., Chen, Y.R., Xiong, J., Feng, Y., Men, D., Huang, Q.C., Liu, Y., Yang, B., Ding, J.Y. and Li, F. (2020) Detectable Serum SARS-CoV-2 Viral Load [RNAemia] Is Closely Correlated with Drastically Elevated Interleukin 6 [IL-6] Level in Critically Ill COVID-19 Patients. Clinical Infectious Diseases. https://doi.org/10.1093/cid/ciaa449

[7] Sultan, S. (2020) Very Impressive Analysis of COVID-19. https://oxycamaras.com.br/very-impressive-analysis-of-covid-19-issue-by-prof-shar if-sultan-president-of-international-society-of-vascular-surgery

[8] Coronavirus Africa Summary: Cases, Deaths...-AS English. https://as.com/

[9] Live Statistics and Coronavirus News Tracking the Number of Confirmed Cases, Recovered Patients, Tests, and Death Toll Due to the COVID-19 Coronavirus from Graphs Hungary United States India. https://www.worldometers.info/coronavirus/?

[10] Coronavirus Live Updates: Deaths and Cases UK, Australia, Canada, Spain... https://en.as.com/en/2020/04/23/other_sports/1587622611_538823.html

[11] Davidson, H. and Beaumont, P. (2020) China Coronavirus Cases May Have Been 
Four Times Official Figure. The Guardian International Edition.

[12] Google COVID-19 Alert. Wikipedia. https://g.co/kgs/ZGAQaa

[13] Africa Records 9106 COVID-19 Recoveries. Africa Centres for Disease Control and Prevention, Africa CDC.

https://guardian.ng/news/world/africa/africa-records-9106-covid-19-recoveries

[14] Coronavirus: Nigeria to Test 2 Million People in 3 Months. NCDC.

https://www.premiumtimesng.com/coronavirus/390405-coronavirus-nigeria-to-test -3-million-people-in-three-months-ncdc.html

[15] Nigeria Carries Out 12,004 COVID-19 Tests Nationwide So Far. https://www.xinhuanet.com/english/2020-04/28/c_139015766.htm

[16] Coronavirus Disease. Wikipedia. https://en.wikipedia.org/wiki/Coronavirus_disease_2019

[17] 2020 Coronavirus Pandemic in Egypt. Wikipedia. https://en.m.wikipedia.org

[18] Senegal Records Largest Single Rise in Virus Infections. https://www.dispatchlive.co.za/news/africa/2020-04-25-senegal-records-largest-sing le-rise-in-virus-infections

[19] 2020 Coronavirus Pandemic in Morocco. Wikipedia. https://en.wikipedia.org/wiki/COVID-19_pandemic_in_Morocco

[20] Coronavirus in Africa Tracker: How Many COVID-19 Cases \& Where. WHO, Johns Hopkins. nCoV.

https://africanarguments.org

[21] COVID-19 Map-Johns Hopkins Coronavirus Resource Center. https://coronavirus.jhu.edu/

[22] African Centres for Diseases Control and Prevention. COVID-19 Dashboard. https://africacdc,org/covid-19

[23] Wallace, D.J., Angus, D.C., Seymour, C.W., Bernato, A.E. and Kahn, J.M. (2015) Critical Care Bed Growth in the United States: A Comparison of Regional and National Trends. American Journal of Respiratory and Critical Care Medicine, 19, 410-416. https://doi.org/10.1164/rccm.201409-1746OC

[24] el-Sadr, W.M. and Justman, J. (2020) Africa in the Path of COVID-19. The New England Journal of Medicine. https://doi.org/10.1056/NEJMp2008193

[25] COVID-Organics: Madagascar Launches Africa's First Cure for Virus. https://www.africanews.com/2020/04/22/covid-organics-madagascar-launches-afric a-s-first-cure-for-virus

[26] Barriers to Mass Testing for COVID-19 in Africa. Atlantic Council. https://www.atlanticcouncil.org/blogs/africasource/barriers-to-mass-testing-for-cov id-19-in-africa

[27] Scientists in Senegal Produce 3-D Ventilators for Patients. https://www.tvcnews.tv/scientists-in-senegal-produce-3-d-ventilators-for-patients

[28] Abuja Declaration: 10 Years On. https://www.who,int/healthsystems/publications/abuja_declaration/en

[29] Nigeria's Heath Care Spending Lags behind Abuja Declaration. https://www.voanews.com/africa/nigerias-health-care-spending-lags-behind-abujadeclaration

[30] Kumar, R. and Pal, R. (2018) India Achieves WHO Recommended Doctor Population Ratio: A Call for Paradigm Shift in Public Health Discourse. Journal of Family 
Medicine and Primary Care, 7, 841-844.

https://www.jfmpc.com/article.asp?issn+2249-4863

[31] Physicians per 1,000 People. Sub-Saharan Africa.

https://data.worldbank.org/

[32] Population by Country (2020) Worldometer.

https://www.worldometers.info/world-population/population-by-country

[33] https://www.share.com>health

[34] COVID-19: Young Inventors, Local Ventilators to Nigeria's.

https://economicconfidential.com/2020/04/covid19-young-inventors-local-ventilato rs/

[35] John Elflein. Countries with the Lowest Physicians' Density Worldwide 2016. http://www.statista.com

[36] Kathryn Diss. The US Was Warned It Could Run Out of Ventilators amid Coronavirus.

http://www.abc.net.au/news/2020-04-12/why-is-the-US-out-of-ventilators-amid.cor onavirus /12137178

[37] Coronavirus Vaccine to Be Tested in UK from Thursday. http://www.independent.co.uk/

[38] South Africa Is Working on Producing 10,000 Ventilators by End of June. http://qz.com/

[39] Making Ventilators in Egypt: Tough But Not Impossible. https://madamasr.com/en/2020/04/11/feature/society/making-ventilators-in-egypt-t ough-but-not-impossible/

[40] Income Per Capita by Country. https://www.worldometers.info/gdp/gdp-per-capita 